\title{
Cannabinoid disruption of learning mechanisms involved in reward processing
}

\author{
Carl R. Lupica and Alexander F. Hoffman \\ Electrophysiology Research Section, National Institute on Drug Abuse Intramural Research Program, National Institutes of Health, \\ Baltimore, Maryland 21224, USA
}

\begin{abstract}
The increasing use of cannabis, its derivatives, and synthetic cannabinoids for medicinal and recreational purposes has led to burgeoning interest in understanding the addictive potential of this class of molecules. It is estimated that $\sim 10 \%$ of marijuana users will eventually show signs of dependence on the drug, and the diagnosis of cannabis use disorder (CUD) is increasing in the United States. The molecule that sustains the use of cannabis is $\Delta^{9}$-tetrahydrocannabinol $\left(\Delta^{9}\right.$-THC), and our knowledge of its effects, and those of other cannabinoids on brain function has expanded rapidly in the past two decades. Additionally, the identification of endogenous cannabinoid (endocannabinoid) systems in brain and their roles in physiology and behavior, demonstrate extensive involvement of these lipid signaling molecules in regulating CNS function. Here, we examine roles for endogenous cannabinoids in shaping synaptic activity in cortical and subcortical brain circuits, and we discuss mechanisms in which exogenous cannabinoids, such as $\Delta^{9}$-THC, interact with endocannabinoid systems to disrupt neuronal network oscillations. We then explore how perturbation of the interaction of this activity within brain reward circuits may lead to impaired learning. Finally, we propose that disruption of cellular plasticity mechanisms by exogenous cannabinoids in cortical and subcortical circuits may explain the difficulty in establishing viable cannabinoid self-administration models in animals.
\end{abstract}

Cannabis is the most widely used illicit substance, with an estimated 183 million users worldwide (United Nations Office on Drugs and Crime 2016). Within the United States, an estimated 24 million people use marijuana, and evidence suggests its use is increasing among those older than 18 (Substance Abuse and Mental Health Services Administration 2017). Although the U.S. Drug Enforcement Administration (DEA) has long classified cannabis as a Schedule-I drug with "no accepted medical use," there appears to be legitimate scientific support for the therapeutic benefits of controlled use of cannabis and its derivatives (Hill 2015; Abrams 2018). In addition to medicinal use, recreational consumption of cannabis is presently legal in nine states in the U.S.A. (Alaska, California, Colorado, Massachusetts, Maine, Nevada, Oregon, Vermont, Washington) (Carliner et al. 2017). Whereas cannabis is often perceived as less harmful than other drugs, considerable evidence suggests that its use is associated with some adverse health effects, and that the potential for chronic abuse is relatively high. The adverse psychiatric effects of cannabinoids have been widely documented, and the diagnosis of cannabis use disorder (CUD) (American Psychiatric Association 2013) has increased over the last decade (Zehra et al. 2018). It is estimated that $10 \%$ of cannabis users will go on to exhibit signs of addiction to the drug, such as craving, loss of control of intake, and continued use despite direct adverse consequences (Lopez-Quintero et al. 2011; Volkow et al. 2014a). Related to this, brain imaging studies demonstrate that region-specific changes in brain function in those diagnosed with CUD overlaps with changes seen in individuals addicted to other abused drugs, such as heroin or cocaine (Koob and Volkow 2016). Importantly, the proportion of individuals receiving the CUD diagnosis increases in those beginning cannabis use in adolescence (Volkow et al. 2017). These potential health risks, and the expanding use of cannabis and $\Delta^{9}$-THC-containing products

Corresponding author: clupica@mail.nih.gov

Article is online at http://www.learnmem.org/cgi/doi/10.1101//m.046748.117. create more urgency in the need to understand the substrates through which cannabinoids exert their effects on the CNS. Here we provide an overview of cannabinoid actions on brain regions central to its effects on cognition, such as the hippocampus and cortex, and we describe how these regions interact with subcortical brain circuits that participate in reward, motivation and drug addiction. Finally, we will examine the hypothesis that widespread dysregulation of these circuits by cannabinoids may prevent the establishment of cannabinoid self-administration models in rodents.

\section{A brief overview of the endocannabinoid system}

The isolation of $\Delta^{9}$ - tetrahydrocannabinol $\left(\Delta^{9}\right.$-THC) as the primary psychoactive constituent of cannabis (Mechoulam and Gaoni 1965) ushered in an active era of neurobiological research. The identification of G-protein-coupled cannabinoid receptors (GPCRs), known as CB1R and CB2R, as the cellular binding sites for $\Delta^{9}$-THC and other synthetic cannabinoids (Devane et al. 1988; Howlett et al. 1990; Munro et al. 1993) represented another milestone that was followed by discovery of endocannabinoids, such as 2-arachidonylglycerol (2-AG) and anandamide (Devane et al. 1992; Stella et al. 1997). Endocannabinoids, like exogenously administered cannabinoids, bind to CB1R and CB2Rs, as well as vanilloid receptors (TRPV1), and other GPCRs, such as GPR55 (Piomelli 2003; Ross 2003; Lauckner et al. 2008; Lu and Mackie 2016). Unlike conventional neurotransmitters, endocannabinoids are not stored in synaptic vesicles, but are synthesized in response to heightened neuronal activity (Walker et al. 1999; Wilson and Nicoll 2002; Brown et al. 2003; Riegel and Lupica 2004; Kano et al. 2009), or during activation of some GPCRs coupled to phospholipases (Varma et al. 2001; Ohno-Shosaku et al. 2002; Riegel and Lupica 2004). As CB1Rs are densely expressed on many axon

This is a work of the US Government. 
terminals in the CNS, endocannabinoids can act in a "retrograde" manner, following their synthesis at postsynaptic somatodendritic sites, to then activate these presynaptic CB1Rs and inhibit transmitter release (Kreitzer and Regehr 2001; Wilson and Nicoll 2001; Kano et al. 2009). In this way endocannabinoids act as ubiquitous modulators of neurotransmitter release.

\section{Cannabinoid regulation of intrinsic hippocampal circuitry}

Among the earliest reported effects of isolated $\Delta^{9}$-THC on behavior was the disruption of working memory in humans (Abel 1970, 1971) and animals (Zimmerberg et al. 1971; Essman 1984; Heyser et al. 1993). As the hippocampus plays a central role in many forms of learning and memory (Scoville and Milner 1957; Drew and Miller 1974), it was hypothesized that $\Delta^{9}$-THC might disrupt these processes through direct actions in this brain area (Drew and Miller 1974; Miller and Branconnier 1983). This hypothesis also relied on evidence showing robust CB1R expression in the hippocampus (Devane et al. 1988; Herkenham et al. 1990; Howlett et al. 1990; Herkenham et al. 1991b). Later work revealed that infusion of cannabinoid agonists into the rodent hippocampus could disrupt spatial memory (Lichtman et al. 1995), and that intrahippocampal delivery of the CB1R antagonist/inverse agonist, rimonabant, blocked the memory-impairing effects of $\Delta^{9}$-THC (Wise et al. 2009). A number of studies have established that CB1Rs are expressed at high levels on GABAergic interneurons that colocalize the neuropeptide, cholecystokinin (CCK), in the hippocampus, and at much lower levels on glutamatergic axon terminals (Tsou et al. 1999; Kawamura et al. 2006; Takahashi and Castillo 2006). The primary function of these hippocampal CB1Rs is to inhibit the release of both GABA (Katona et al. 1999; Hoffman and Lupica 2000) and glutamate (Shen et al. 1996; Misner and Sullivan 1999; Sullivan 2000) through coupling to either voltage dependent $\mathrm{Ca}^{2+}$ or potassium channels (Twitchell et al. 1997; Hampson et al. 2000; Hoffman and Lupica 2000; Robbe et al. 2001). Cannabinoid receptors are also found at moderate to high concentrations throughout other cortical and limbic brain circuits, and as discussed below, the inhibition of ongoing synaptic transmission by $\Delta^{9}$-THC and other cannabinoids leads to widespread dysregulation of these networks.

\section{Cannabinoid disruption of synchronized hippocampal networks}

Several studies support the idea that cortical output tightly regulates the activity of subcortical nuclei via coordinated GABAergic interneuron activity (Cobb et al. 1995; Allen and Monyer 2015). An important class of these interneurons known as "basket cells" is found throughout cortical and hippocampal areas. These cells form dense basket-like synaptic contacts on and near the somata of cortical glutamatergic pyramidal neurons (PNs) (Freund and Buzsaki 1996; Pelkey et al. 2017), and the perisomatic location of this inhibition permits potent control of PN firing that is also widespread because each basket cell may contact hundreds to thousands of PNs. These properties allow these GABAergic cells to thereby coordinate the timing and strength of hippocampal and cortical output via regulation of PN activity. Many perisomatic basket cells express either the neuropeptide parvalbumin (PV) or CCK, and these cells have central roles in synchronizing PN output (Cobb et al. 1995; Freund and Buzsaki 1996; Klausberger et al. 2005; Mann and Paulsen 2007). This synchronization is important because oscillation of the activity of large ensembles of neurons at theta $(4-14 \mathrm{~Hz})$ and gamma $(30-80 \mathrm{~Hz})$ frequencies is permissive to the encoding of hippocampal-dependent memory (Cobb et al.
1995; Chapman and Lacaille 1999; Nagode et al. 2014; Trimper et al. 2017). Moreover, widespread synchronized oscillations between hippocampal and cortical neurons are also observed during specific behavioral tasks (Singer 1999; Varela et al. 2001; Fujisawa and Buzsaki 2011; Kucewicz et al. 2011; Solomon et al. 2017), and $\mathrm{PV}$ and CCK interneurons play a critical role in coordinating this network activity (Klausberger et al. 2005; Kim et al. 2016). Although both PV and CCK interneurons are known to drive network oscillations, PV cells have been proposed to play a more predominant role, particularly in synchronizing theta oscillations (Klausberger et al. 2005; Losonczy et al. 2010) and in the generation of sharp wave ripple (SWR) oscillations that are critical to the stabilization of recently learned behaviors (Schlingloff et al. 2014; Buzsaki 2015; Colgin 2016; Gan et al. 2017). However, emerging evidence also suggests that CCK interneurons play different, but no less important roles in regulating cortical networks (Klausberger et al. 2005; Nagode et al. 2014; Del Pino et al. 2017). As mentioned above, CCK interneurons abundantly express CB1Rs (Katona et al. 1999; Marsicano and Lutz 1999), and at full agonist occupation CB1Rs can inhibit electrically activated synaptic GABA release by $\sim 50 \%$ (Hoffman and Lupica 2000; Laaris et al. 2010). Thus, widespread suppression of GABA release can be maintained by $\Delta^{9}$-THC and other cannabinoids, leading to extensive suppression of cortical network activity, including theta and ripple oscillations (Hajos et al. 2000, 2008; Robbe et al. 2006; Robbe and Buzsaki 2009; Raver and Keller 2014). Moreover, although reductions in GABA release appear to be critical for the memory-disrupting effects of $\Delta^{9}$-THC (Puighermanal et al. 2009), cannabinoid inhibition of glutamate release also likely contributes to altered network synchronization (Maier et al. 2012; Buzsaki 2015; Monory et al. 2015). As this oscillatory network activity is also necessary to support several behavioral and cognitive states through hippocampal outputs to various downstream targets (Yamamoto et al. 2014; Solomon et al. 2017; Tamura et al. 2017), it is hypothesized that this represents a critical mechanism through which cannabinoids disrupt learning, memory, and other forms of cognition (Robbe and Buzsaki 2009; Hampson et al. 2011; Kucewicz et al. 2011).

\section{Hippocampal connections with reward and motivational circuits}

\section{Hippocampal-VTA circuitry}

Strong evidence shows that hippocampal efferents directly and indirectly alter midbrain DA neuron activity. Thus, ventral hippocampal neurons can increase the activity of nucleus accumbens (NAc) medium spiny neurons, which in turn synapse upon ventral pallidal cells, that synapse on VTA DA neurons (Lisman and Grace 2005). Through this circuit, ventral hippocampal output increases DA levels in cortical areas, likely playing a central role in permitting the attribution of salience to events within particular behavioral contexts (Berridge 2007, 2012). In support of this, reinstatement of previously extinguished cocaine-seeking behavior is elicited following theta pattern stimulation of the ventral subiculum, a major hippocampal output pathway, and this is blocked by intra-VTA glutamate receptor antagonism (Vorel et al. 2001). Additionally, inactivation of the dorsal subiculum blocks reinstatement of cocaine seeking evoked by exposure to conditioned contextual cues that predict the drug's availability (Martin-Fardon et al. 2008). Also, when hippocampal place cell firing is used to drive forebrain DA release via intracranial stimulation of the medial forebrain bundle, animals demonstrate conditioned place preference mapped to specific place cells (de Lavilléon et al. 2015).

Another hippocampal output receiving less experimental attention than the ventral hippocampal pathway, arises from the dorsal CA3 area. When activated by theta stimulation, these 
pyramidal projection neurons activate neurons in the lateral septum, which then send output to the VTA, ultimately increasing DA neuron activity (Luo et al. 2011). Behavioral studies show that this circuit is activated by exposure to conditioned contextual cues and is involved in the reinstatement of drug-seeking by these cues (Fuchs et al. 2005; Luo et al. 2011; McGlinchey and Aston-Jones 2018). Thus, as increased ventral (Bossert et al. 2016; Marchant et al. 2016) and dorsal hippocampal output can reinstate drug-seeking, it appears that the hippocampus is involved in encoding drug-reward context, which is then communicated to brain areas mediating reward and motivation.

Given the strong influence of cannabinoids on the hippocampal circuitry and the ability of hippocampal outputs to activate midbrain DA neurons, it is reasonable to predict that hippocampal CB1Rs can influence brain reward circuitry. A recent study examining this found that infusion of the cannabinoid agonist WIN55,212-2 into the ventral hippocampus increased the activity of VTA DA neurons, facilitated morphine conditioned place preference, and impaired social recognition behaviors (Loureiro et al. 2015). Moreover, these behavioral alterations were reversed by infusion of the nonselective dopamine receptor antagonist $\alpha$-flupenthixol into the NAc. These data support the idea that activation of hippocampal CB1Rs by exogenous cannabinoids can influence midbrain reward circuitry.

\section{Hippocampal-NAc circuitry}

The NAc receives dense innervation from the major hippocampal output pathway known as the ventral subiculum (Groenewegen et al. 1987; French and Totterdell 2002), and optogenetic activation of the hippocampal-NAc pathway reinforces instrumental behavior (Britt et al. 2012). In addition, there is now evidence for a unique population of hippocampal CA1 and subicular neurons that encode reward independent of spatial context (Gauthier and Tank 2018). It is thought that during synchronized activity the ventral hippocampal input to the NAc conveys spatial information serving to guide motivated behavior (Ito et al. 2008; Pennartz et al. 2011; Lansink et al. 2016), and that the coherent patterns of theta activity observed during goal-directed behavior is critical to this process in rodents (Gruber et al. 2009; van der Meer and Redish 2011). A recent human study also revealed that low-frequency coherence is present between cortical and NAc circuits, both during decision-making tasks and when subjects are quietly sitting at rest (Stenner et al. 2015). In addition, evidence suggests that hippocampal theta rhythm magnitude scales to increased expected reward probability, implying that dynamic changes in theta can also convey reward information (Tryon et al. 2017). As it is welldocumented that hippocampal theta oscillation is involved in guiding motivated behavior (van der Meer and Redish 2011; Wikenheiser and Redish 2015; Lansink et al. 2016), disruptions to theta activity produced by cannabinoids (Hajos et al. 2000; Robbe and Buzsaki 2009; Kucewicz et al. 2011) would therefore be predicted to profoundly disrupt signaling between hippocampal and ventral striatal circuits. Although this hypothesis has not yet been examined, it would seem to be an important area for future investigation.

\section{VTA-hippocampal circuitry}

In addition to influencing DA neuron activity, the hippocampus also receives DA input that modulates synaptic plasticity (Otmakhova and Lisman 1996; Lisman et al. 2011). Thus, activation of DA-D1/D5 receptors strengthens hippocampal long-term potentiation (Otmakhova and Lisman 1996; Hansen and ManahanVaughan 2014), and activation of DA-D4 receptors promotes depotentiation (Izumi and Zorumski 2017). This hippocampus $\rightarrow$ midbrain $\rightarrow$ hippocampus loop therefore comprises a feedback circuit that is likely permissive to the coupling of midbrain DA-mediated reward signals to hippocampal encoding of spatiotemporal context (Lisman and Grace 2005; Rossato et al. 2009). This idea has received support from both animal (Singer and Frank 2009; Tryon et al. 2017), and human (Gruber et al. 2016; Richter and Gruber 2018) studies in which DA-mediated reward output strengthens hippocampal-dependent long-term memories. In addition, intrahippocampal blockade of D1/D5 receptors impairs the ability of rats to learn novel reward-location associations that depend on hippocampal place cell activity (Retailleau and Morris 2018).

One mechanism that may serve to bind hippocampal and to brain reward circuit activity is the ability of hippocampal circuits to "replay" recently encoded events during periods of sleep or rest (Foster and Wilson 2006; Ólafsdóttir et al. 2018). This phenomenon is characterized by later replay of bouts of SWR oscillations by hippocampal place cells that were initially encoded during learning procedures (Karlsson and Frank 2009; Colgin 2016). Importantly, the replay of these SWR patterns is temporally condensed (100-300 msec), compared to the original place cell firing patterns (Foster 2017), and replay in awake animals can occur in either the same (forward) or opposite (reverse) direction as that observed during behavior (Foster and Wilson 2006; Diba and Buzsaki 2007). Evidence for association of these patterns with brain reward circuits comes from studies showing that both reverse replay and hippocampal SWRs are sensitive to changes in reward magnitude (Ambrose et al. 2016), and with the observation that rewardresponsive VTA neuron activity patterns are coordinated with SWRs during periods of quiet wakefulness (Gomperts et al. 2015). Moreover, DA enhances SWRs in the in vitro hippocampus (Miyawaki et al. 2014), and D1/D5 receptors regulate learninginduced plasticity of PV interneurons that regulate SWRs (Schlingloff et al. 2014; Karunakaran et al. 2016). Currently, the most direct evidence for DA modulation of SWRs comes from a study in which optogenetic activation of hippocampal DA terminals during novel environment exploration promoted reactivation of SWRs recorded during sleep, and this stabilized learning on a spatial maze task (McNamara et al. 2014). Collectively, these studies suggest that hippocampal DA release facilitates the encoding of long-term memory through modulation of SWRs, and that there is coordination between hippocampal and reward circuits during this process. The known ability of exogenously administered cannabinoids to disrupt SWRs (Robbe and Buzsaki 2009; Maier et al. 2012) would therefore be predicted to limit the role these oscillations play in coordinating hippocampal and midbrain activity, and hence disrupt the encoding of recently rewarded behavior (Fig. 1).

\section{Endocannabinoid modulation of cortical circuitry}

Whereas $\Delta^{9}$-THC and synthetic cannabinoids are known to impair cortical circuitry via activation of CB1Rs on CCK interneuron and glutamatergic axon terminals, increasing evidence suggests that endocannabinoids are involved in maintaining the synchronization of cortical networks (Skosnik et al. 2016; Lupica et al. 2017). An example of this can be seen in the interplay among hippocampal interneurons. Thus, the neuropeptide CCK can depolarize PV-containing interneurons by activating somatodendritic $\mathrm{CCK}_{\mathrm{B}}$ receptors, and this increases GABA release onto PNs (Miller et al. 1997). However, CCK also simultaneously suppresses GABA release from CCK-positive cells via activation of CB1Rs by an endocannabinoid (Foldy et al. 2007; Karson et al. 2008). Although the cellular source of the endocannabinoid is not known, its release could be from either PV interneurons, upon depolarization by CCK, or from PNs, since both cell populations express diacylglycerol 


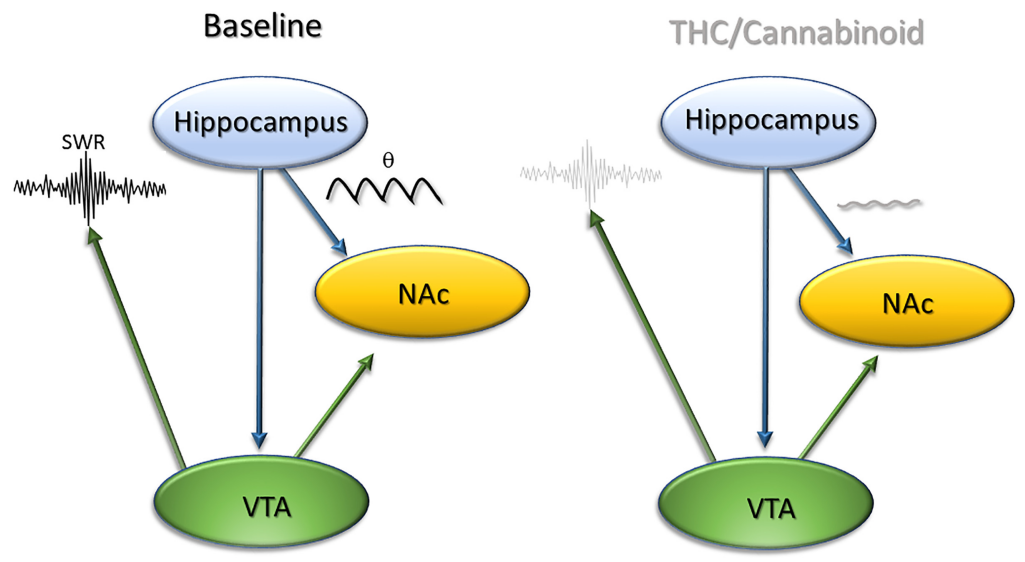

Figure 1. Disruption of hippocampal networks by THC. In normal conditions, hippocampal theta $(\theta)$ oscillations (during exploration) help to encode the animal's location. During consummatory periods, or during "quiet rest," SWRs reactivate patterns of activity, helping to consolidate locations into long-term memory. DA release, which is facilitated through hippocampal activation (either from ventral subiculum or via the CA3-lateral septal circuit), feeds back to promote reactivation by SWRs. In the presence of THC or other cannabinoid agonists, SWRs and theta activity are disrupted, potentially limiting both hippocampal-NAc coupling and the ability of DA to promote hippocampal reactivation.

lipase- $\alpha$ (DGL- $\alpha$ ), an enzyme necessary for 2-AG synthesis (Katona et al. 2006; Peterfi et al. 2012). Regardless of its site of origin, the ability of 2-AG to preferentially suppress GABA release from CCK basket cells would likely cause a shift in the control of hippocampal network activity by both CCK and PV interneurons, to that predominantly controlled by PV interneurons alone (Foldy et al. 2007). Furthermore, the 2-AG suppression of CCK interneuron-mediated inhibition of hippocampal PNs increases excitation of these cells via collateral glutamatergic inputs, thereby promoting increased hippocampal output (Chevaleyre and Piskorowski 2014).

Although these investigations make it clear that 2-AG can act via these mechanisms to alter the activity of hippocampal circuits, at present there are only limited studies implicating endocannabinoids in the control of synchronized neuronal oscillations. One of these investigations reported no effect of the antagonist rimonabant on hippocampal neural oscillations, even at doses that blocked the disruption of network activity by an exogenous CB1R agonist (Robbe et al. 2006). However, though not directly assessing endocannabinoid function in network oscillations, there is extensive evidence implicating their involvement in memory encoding, which as described above, is thought to rely upon coherent network activity. Thus, the encoding of hippocampal ensemble activity during delayed nonmatch to sample (DNMS) short term memory tasks, and performance of these tasks after longer delays, is increased by rimonabant (Deadwyler and Hampson 2008). Moreover, systemic administration of rimonabant enhances spatial learning in delayed radial arm maze tasks (Lichtman 2000; Wolff and Leander 2003), but impairs performance when given prior to acquisition in a water maze task (Robinson et al. 2008). Interestingly, performance improves on both the water maze (Robinson et al. 2008) and the DNMS task (Hampson et al. 2011) when rimonabant is infused within the hippocampus, suggesting that endocannabinoids may be involved in limiting the encoding of certain types of memory and this can be prevented by CB1R antagonists. Arguing against this however is the observation that intrahippocampal infusion of the CB1R antagonist AM251 impairs inhibitory avoidance learning (de Oliveira Alvares et al. 2005). Thus, specific roles for endocannabinoids in supporting hippocampal function may depend upon the behavioral task that is assessed, as well as the emotional state of the animal (Morena and Campolongo 2014). It should also be noted that cortical anandamide levels may play a role in modulating the animal's response to stress (McLaughlin et al. 2012). As these studies indicate, reaching definitive conclusions regarding the involvement of endocannabinoids in memory processes and in regulation of neuronal oscillations is difficult because of the reliance on CB1R ligands possessing inverse agonist/antagonist properties. Therefore, it is difficult to conclude that a particular finding obtained with these ligands results from antagonism of endocannabinoid function, as opposed to activation of the receptor through inverse agonism. However, "neutral" cannabinoid antagonists lacking these inverse agonist properties are increasingly available, and CB1R positive allosteric modulation appears a promising strategy to augment endocannabinoid effects (Vandevoorde 2008; Vemuri and Makriyannis 2015; Khurana et al. 2017). Therefore, future studies utilizing these approaches should increase our understanding of roles for the endocannabinoids in mediating hippocampal function.

\section{Endocannabinoid modulation of reward circuitry}

Numerous early studies demonstrated that the activity of midbrain DA neurons is enhanced by CB1R activation (French 1997; French et al. 1997; Cheer et al. 2003), and that this leads to increased DA release from axon terminals in the NAc (Ng Cheong Ton et al. 1988; Tanda et al. 1997; Cheer et al. 2007). Since CB1Rs are not expressed on DA neurons (Herkenham et al. 1991a; Julian et al. 2003), control of DA neuron activity by cannabinoids is dependent on modulation of synaptic inputs to these cells (Lupica et al. 2004; Melis et al. 2004b; Riegel and Lupica 2004). Thus, it is hypothesized that the increase in midbrain DA neuron activity caused by $\Delta^{9}$-THC and other cannabinoids results from the suppression of GABA release, causing "disinhibition" of these cells (Lupica et al. 2004). The activity-dependent release of endocannabinoids within the VTA is also now well-established (Wang and Lupica 2014), and it is thought that this might provide a means for feedback control of various cortical or subcortical inputs to DA neurons (Melis et al. 2004b; Kortleven et al. 2011; Wang and Lupica 2014). Moreover, there is emerging evidence showing that local VTA endocannabinoid production is involved in maintaining reward-related behaviors. For example, Oleson et al. (2012) demonstrated that in rats trained to associate a cue with rewarding intracranial self-stimulation (ICSS), presentation of the cue alone can elicit DA release in the NAc. However, if the presentation of this cue is preceded by intra-VTA injection of rimonabant, the cue-induced increase in DA is prevented (Oleson et al. 2012). Moreover, similar effects are observed when animals are engaged in food seeking behavior (Oleson et al. 2012), suggesting that endocannabinoids act in the VTA to promote reward-associated DA signaling. More direct evidence for control of DA neuron output by endocannabinoids acting in the VTA comes from a study in which the increase in NAc DA release evoked by systemic cocaine was significantly attenuated by preceding intra-VTA infusions of CB1R antagonists (Wang et al. 2015). Moreover, the biosynthetic enzyme for 2-AG, DGL $\alpha$, is found in DA and non-DA neurons in the VTA (Mátyás et al. 2008), and its inhibition 
by intra-VTA injection of tetrahydrolipostatin (THL), was also effective in reducing the ability of systemic cocaine to increase NAc DA release (Wang et al. 2015). These data suggest that part of cocaine's rewarding effect is mediated by VTA 2-AG release, and that cocaine can mobilize this endocannabinoid in the VTA. In support, this study also showed that cocaine could stimulate the synthesis of 2-AG in the VTA via the inhibition of norepinephrine uptake. This leads to activation of $\alpha_{1}$-adrenergic $\mathrm{G}_{\mathrm{q} 11}$-coupled receptors that stimulate phospholipase-C- $\beta$ to liberate membranous 2-AG precursors (Wang et al. 2015). Together, these data support the idea that cocaine mobilizes 2-AG from VTA DA neurons, which then suppresses GABAergic input to these cells, thereby promoting enhanced firing. However, it should also be noted that 2-AG can act directly to inhibit potassium currents on VTA DA neurons to promote burst firing, even in the absence of synaptic input (Gantz and Bean 2017), and that VTA GABAergic neurons can release 2-AG, and this can suppress glutamate inputs to these cells (Friend et al. 2017). Since GABAergic VTA neurons have been demonstrated to both enhance DA cell activity (Bocklisch et al. 2013) and modulate reward via direct output to the NAc (Brown et al. 2012), this provides another potential substrate for endocannabinoid control of VTA output (Fig. 2). Finally, an intriguing recent study revealed that 2-AG modulation of VTA neuron output also plays an essential role in an active avoidance task in which rats learn to press a lever to avoid footshock (Wenzel et al. 2018), and there is strong evidence for anandamide regulation of basolateral amygdala neuron activity to control fear and anxiety (GunduzCinar et al. 2013). These data are consistent with a wider role for endocannabinoids in the control of DA release, and in the encoding of salient stimuli in both rewarding and aversive contexts (Flagel et al. 2011; Wenzel et al. 2015), and such interactions might be especially important in negative emotional states observed in drug addiction (Parsons and Hurd 2015; Zlebnik and Cheer 2016). In summary, the contribution of endocannabinoids to shaping the ongoing activity patterns of midbrain DA neurons indicate that they may play an important role in sculpting learned responses to a wide range of environmental stimuli. Therefore, we hypothesize that disruption of endocannabinoid signaling by

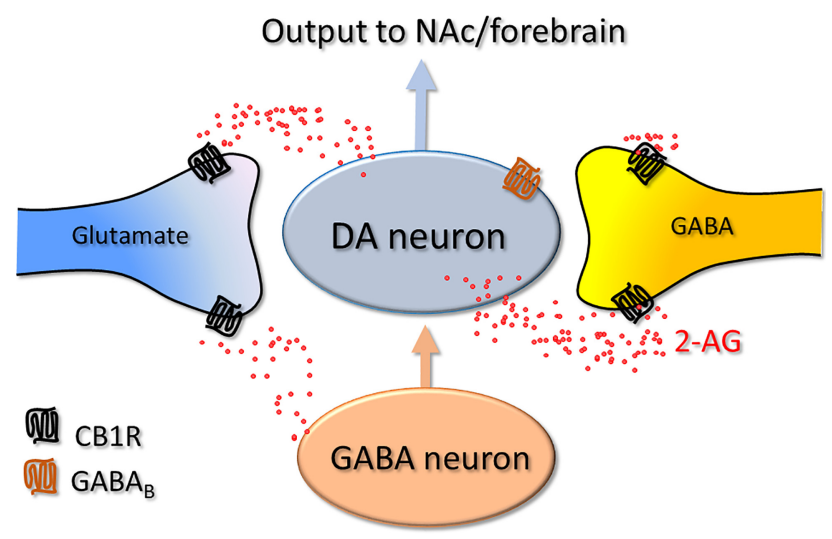

Figure 2. Endocannabinoid regulation of VTA output. 2-AG Released by DA neurons during periods of high activity (bursting or enhanced glutamatergic input) feeds back to presynaptically inhibit GABA release onto GABA-B receptors. This disinhibits DA cells, leading to enhanced DA output from projection terminals. In addition, 2-AG released from GABA cells in the VTA produces long-lasting depression of excitatory transmission onto these cells (Friend et al. 2017). Reduced excitation of local GABA cells by endocannabinoids within the VTA may also promote activation through disinhibition of DA neurons (see Bocklisch et al. 2013) or reduce GABA release in the NAC that is necessary for encoding reward (Brown et al. 2012). THC and other cannabinoids would disrupt these ongoing signaling pathways, and perhaps alter the timing of DA output.
$\Delta^{9}$-THC or synthetic cannabinoids might impair learning processes in which the midbrain DA system is involved.

\section{Dysfunction of DA and cortical circuitry following long-term use of cannabinoids}

Based on the findings presented above, there is ample evidence to suggest that endocannabinoids act within both cortical and subcortical circuits to influence reward and learning behavior and that acute exposure to $\Delta^{9}$-THC and other cannabinoid agonists can disrupt cortical networks and impair cognitive function. Thus, the continued use of cannabinoids for therapeutic or recreational purposes carries risk for long-term disruptions in neural function, and, considering the addictive potential of cannabinoids, the possible progression to CUD. Here we review some of the human and animal studies relating to these possibilities.

Long-term cognitive deficits have been observed following repeated use of cannabis in some human studies (Bolla et al. 2002; Lundqvist 2005; Meier et al. 2012), but this has not been supported by other investigations (Pope et al. 1995; Crean et al. 2011). It has been suggested that long-term changes in brain function may be more pernicious if use begins during adolescence, which may reflect disruption of ongoing cortical development during this age (Brook et al. 2008). In support of this, recent studies in animals show that repeated exposure of adolescent mice to cannabinoids leads to changes in cortically recorded network oscillations that persist into adulthood (Raver et al. 2013; Raver and Keller 2014), and this is consistent with the clinical findings of impaired gamma oscillations in heavy cannabis users (Skosnik et al. 2014). Similarly, in rats repeatedly given the cannabinoid agonist WIN55,212-2 during adolescence, GABA release is impaired in the prefrontal cortex during adulthood, and this leads to disinhibition of cortical output (Cass et al. 2014). Changes in synaptic morphology across cortical and limbic brain areas have also been recently described in rats following chronic $\Delta^{9}$-THC treatment (Kolb et al. 2018), and changes in NAc spine density and synaptic function have been observed following extinction of $\Delta^{9}$-THC self-administration (Spencer et al. 2018). In addition, changes in DA function following repeated cannabinoid exposure have been described in both animals (Jentsch et al. 1998; Verrico et al. 2003; Pistis et al. 2004) and humans (Volkow et al. 2014b; van de Giessen et al. 2016). In animal studies, chronic cannabinoid treatment is associated with sensitization of dopamine D2 receptors in the striatum and NAc (Ginovart et al. 2012; Tournier et al. 2016), although changes in D2 receptor availability have not been consistently observed in human imaging studies (Ghazzaoui and Abi-Dargham 2014; Bloomfield et al. 2016). It is possible that, like adaptations in cortical circuitry, changes in DA systems are dependent on factors such as the onset age of use and duration of exposure (Bloomfield et al. 2014; Ghazzaoui and Abi-Dargham 2014; Volkow et al. 2016b). Additional studies will be required to definitively establish the extent to which DA and cortical systems undergo adaptations following repeated use of cannabinoids, and to what degree their use in adolescence leads to more enduring changes in brain function.

Current working models define drug addiction as a compulsive process characterized by loss of control over intake and the emergence of negative cognitive and emotional states when drug use is absent (Koob and Volkow 2016). Each of these phenomena involves a variety of neuroanatomical circuits, and alterations in these brain areas following long-term drug exposure can contribute to the chronic relapsing nature of drug addiction (Hyman and Malenka 2001; Volkow et al. 2016a). Within this framework, cannabinoids clearly display certain hallmarks of addictive drugs, such as the ability to increase forebrain DA release (Ng Cheong 
Ton et al. 1988; Tanda et al. 1997; Bossong et al. 2015), although not to the levels typically observed with psychostimulants (Zehra et al. 2018). In addition, cannabis withdrawal symptoms that include irritability, anxiety, depression, and sleep disturbance have been well described (Budney and Hughes 2006; Katz et al. 2014), and are consistent with the Koob and Volkow model (Koob and Volkow 2016). Although conditioned place preference (Lepore et al. 1995; Murray and Bevins 2010) models have established that $\Delta^{9}$-THC appears rewarding at low concentrations $(\sim 1 \mathrm{mg} /$ $\mathrm{kg}$ ), reliable models of self-administration of cannabinoids in rodents have been difficult to develop. This has constrained our knowledge of the neurobiological mechanisms involved in compulsive use and relapse to drug seeking following its withdrawal (Belin-Rauscent et al. 2016). Below, we address potential impediments to developing these models in rodents.

\section{Hypothesis: the failure of rodents to self-administer cannabinoids is a network problem}

Despite their ability to evoke NAc DA release (Wise and Bozarth 1987; Koob 1992; Tanda et al. 1997; Oleson and Cheer 2012), and their voluntary use in humans, there has been considerable difficulty in developing reliable rodent models of cannabinoid selfadministration (Justinova et al. 2005; Panlilio and Justinova 2018). Although, as has been suggested, the lack of solubility of these hydrophobic compounds and other pharmacodynamic issues may limit their efficacy in these models (Melis et al. 2017), we propose that the ability of cannabinoids to act to disrupt the function of widespread neural networks may also contribute to this problem. As we discuss above, exogenous cannabinoids like $\Delta^{9}$-THC likely act at several sites to disrupt ongoing network activity, and strong evidence demonstrates that output from hippocampal CA3 and CA1 subfields impinge on major midbrain DA nuclei that contribute to both drug-seeking behavior and to assigning salience to environmental cues (Vorel et al. 2001; Luo et al. 2011; McGlinchey and Aston-Jones 2018). In addition, there is now evidence for a discrete population of hippocampal neurons that directly encode reward (Gauthier and Tank 2018). Given the extensive actions of cannabinoids in the hippocampus, we hypothesize that the activity of these reward-encoding neurons is also modulated by these molecules. We also discuss data that suggest that one of the primary roles of hippocampal DA receptors, activated by either VTA DA inputs or locus coeruleus noradrenergic inputs (Kempadoo et al. 2016; Takeuchi et al. 2016), is likely to strengthen learned associations by facilitating memory consolidation via enhanced network activity (McNamara et al. 2014). Given that coherent patterns of network activity are observed between the hippocampus and ventral striatum during reward processing (Gruber et al. 2009; Lansink et al. 2009, 2016), it is likely that this dopaminergic strengthening of hippocampal networks would be found in other brain regions as well (Sjulson et al. 2018). Therefore, we suggest that by impairing the coherence of neuronal oscillations across cortical and subcortical networks, cannabinoids may compromise an important substrate through which DA acts to facilitate learning necessary to support performance in operant paradigms used to evaluate self-administration. In this context, it is relevant that although hippocampal theta activity is commonly associated with spatial learning, recent evidence suggests that this form of network activity is also involved in operant behavioral tasks (Santos et al. 2008; Jurado-Parras et al. 2013). Although at present it is not clear why $\Delta^{9}$-THC self-administration is observed more reliably in nonhuman primates compared to rodents (Justinova et al. 2003; Panlilio et al. 2010), it is possible that procedural differences between these models, such as the use of chair restraint in nonhuman primates, may contribute, since hippocampal neuronal activity differs extensively in restrained versus freely moving animals (Foster et al. 1989; O'Mara 1995; Ludvig et al. 2004). Moreover, the observations that $\Delta^{9}$-THC impairs operant responding for ICSS and for food reward in mice (Wiebelhaus et al. 2015) and rhesus monkeys (John et al. 2017) suggest that there may be a general impairment in cognitive processes necessary to support operant reinforcement learning. Given the well-known known ability of cannabinoids to impair learning and memory across a wide range of behaviors (Abel 1970), it is not surprising that operant tasks would also be sensitive to these drugs. Therefore, we suggest that the inability of $\Delta^{9}$-THC and other cannabinoid agonists to support robust operant self-administration, rather than reflecting the absence of reward engendered by the drug, might primarily reflect the inability of cortical networks to encode learning related processes necessary to establish or maintain the operant response.

In addition to this role for cortical circuits in the establishment of the operant responses necessary for cannabinoid selfadministration, the disruption of reward processing within the VTA might also be involved. As described previously, there is growing evidence to suggest that endocannabinoids released from VTA DA neurons play a crucial role in attributing salience to a variety of positive and negative stimuli (Oleson et al. 2012; Wang et al. 2015; Wenzel et al. 2018). Thus, during periods of strong activation, perhaps driven by cortical activity, 2-AG released from DA neurons can feedback on either glutamatergic (Melis et al. 2004a,b) or GABAergic synaptic inputs to VTA DA neurons (Riegel and Lupica 2004; Wang et al. 2015) to alter DA release. In addition, 2-AG released from GABA cells suppresses excitatory inputs to these neurons, which might also enhance DA neuron activity via disinhibition (Bocklisch et al. 2013; Friend et al. 2017). As described above, the temporal coordination of DA signaling is critical to facilitating long-term encoding of information relevant to the behavioral context through its actions within hippocampal or other cortical networks (Nasser et al. 2017). Alternatively, the DA signal could carry motivational aspects of behavior that dynamically interact with previously learned associations to promote reward-seeking behavior (Berridge 2012). In either case, $\Delta^{9}$-THC and other cannabinoids may, by impairing endocannabinoid function within the VTA, limit the ability of DA to signal salience within a given environmental context (Berridge 2007, 2012; Oleson and Cheer 2012). Thus, exposure to exogenous cannabinoids within these circuits may limit progression to sustained self-administration of these drugs.

\section{Summary}

In this review, we have highlighted the ability of $\Delta^{9}$-THC and other cannabinoids to disrupt cortical networks and have presented work that demonstrates widespread implications for these changes on learned behaviors. We suggest that many of the actions of these drugs are attributable to their ability to impair the ability of endocannabinoids to both regulate cortical output and influence downstream brain reward and motivational circuits. In addition, an emerging role for endocannabinoids in regulating VTA DA neuron responsiveness to a variety of salient stimuli suggests that $\Delta^{9}$-THC may alter the ability of these neurons to properly encode adaptive behaviors. We also suggest that the impairment of both learning and motivational network function by cannabinoids may partly explain the difficulty in establishing reliable self-administration models in rodents. Although at present the absence of these models has limited our knowledge of the dynamics of cannabinoid addiction, and by analogy CUD, alternate approaches toward establishing self-administration models, such as using combined $\Delta^{9}$-THC/cannabidiol preparations (Melis et al. 2017; Spencer et al. 2018), may prove useful in the future. Given the increasing 
use of $\Delta^{9}$-THC and synthetic cannabinoids for both medicinal and recreational purposes, it is important to continue to investigate these issues so that we may more fully understand the neurobiological consequences of long-term exposure to cannabinoid drugs.

\section{Acknowledgments}

Supported by the National Institute on Drug Abuse Intramural Research Program.

\section{References}

Abel EL. 1970. Marijuana and memory. Nature 227: 1151-1152.

Abel EL. 1971. Retrieval of information after use of marihuana. Nature 231: 58 .

Abrams DI. 2018. The therapeutic effects of Cannabis and cannabinoids: an update from the National Academies of Sciences, Engineering and Medicine report. Eur J Intern Med 49: 7-11.

Allen K, Monyer H. 2015. Interneuron control of hippocampal oscillations. Curr Opin Neurobiol 31: 81-87.

Ambrose RE, Pfeiffer BE, Foster DJ. 2016. Reverse replay of hippocampal place cells is uniquely modulated by changing reward. Neuron $\mathbf{9 1}$ : 1124-1136.

American Psychiatric Association. 2013. Diagnostic and statistical manual of mental disorders, 5th ed. American Psychiatric Association, Arlington, VA.

Belin-Rauscent A, Fouyssac M, Bonci A, Belin D. 2016. How preclinical models evolved to resemble the diagnostic criteria of drug addiction. Biol Psychiatry 79: 39-46.

Berridge KC. 2007. The debate over dopamine's role in reward: the case for incentive salience. Psychopharmacology (Berl) 191: 391-431.

Berridge KC. 2012. From prediction error to incentive salience: mesolimbic computation of reward motivation. Eur J Neurosci 35: 1124-1143.

Bloomfield MA, Morgan CJ, Egerton A, Kapur S, Curran HV, Howes OD. 2014. Dopaminergic function in cannabis users and its relationship to cannabis-induced psychotic symptoms. Biol Psychiatry 75: 470-478.

Bloomfield MAP, Ashok AH, Volkow ND, Howes OD. 2016. The effects of $\Delta^{9}$-tetrahydrocannabinol on the dopamine system. Nature 539: 369-377.

Bocklisch C, Pascoli V, Wong JC, House DR, Yvon C, de Roo M, Tan KR, Luscher C. 2013. Cocaine disinhibits dopamine neurons by potentiation of GABA transmission in the ventral tegmental area. Science 341: $1521-1525$.

Bolla KI, Brown K, Eldreth D, Tate K, Cadet JL. 2002. Dose-related neurocognitive effects of marijuana use. Neurology 59: 1337-1343.

Bossert JM, Adhikary S, St Laurent R, Marchant NJ, Wang HL, Morales M, Shaham Y. 2016. Role of projections from ventral subiculum to nucleus accumbens shell in context-induced reinstatement of heroin seeking in rats. Psychopharmacology (Berl) 233: 1991-2004.

Bossong MG, Mehta MA, van Berckel BN, Howes OD, Kahn RS, Stokes PR. 2015. Further human evidence for striatal dopamine release induced by administration of 9-tetrahydrocannabinol (THC): selectivity to limbic striatum. Psychopharmacology (Berl) 232: 2723-2729.

Britt JP, Benaliouad F, McDevitt RA, Stuber GD, Wise RA, Bonci A. 2012. Synaptic and behavioral profile of multiple glutamatergic inputs to the nucleus accumbens. Neuron 76: 790-803.

Brook JS, Stimmel MA, Zhang C, Brook DW. 2008. The association between earlier marijuana use and subsequent academic achievement and health problems: a longitudinal study. Am J Addict 17: 155-160.

Brown SP, Brenowitz SD, Regehr WG. 2003. Brief presynaptic bursts evoke synapse-specific retrograde inhibition mediated by endogenous cannabinoids. Nat Neurosci 6: 1048-1057.

Brown MT, Tan KR, O'Connor EC, Nikonenko I, Muller D, Luscher C. 2012. Ventral tegmental area GABA projections pause accumbal cholinergic interneurons to enhance associative learning. Nature 492: 452-456.

Budney AJ, Hughes JR. 2006. The cannabis withdrawal syndrome. Curr Opin Psychiatry 19: 233-238.

Buzsaki G. 2015. Hippocampal sharp wave-ripple: a cognitive biomarker for episodic memory and planning. Hippocampus 25: 1073-1188.

Carliner H, Brown QL, Sarvet AL, Hasin DS. 2017. Cannabis use, attitudes, and legal status in the U.S.: a review. Prev Med 104: 13-23.

Cass DK, Flores-Barrera E, Thomases DR, Vital WF, Caballero A, Tseng KY. 2014. CB1 cannabinoid receptor stimulation during adolescence impairs the maturation of GABA function in the adult rat prefrontal cortex. Mol Psychiatry 19: 536-543.

Chapman CA, Lacaille JC. 1999. Intrinsic theta-frequency membrane potential oscillations in hippocampal CA1 interneurons of stratum lacunosum-moleculare. J Neurophysiol 81: 1296-1307.
Cheer JF, Kendall DA, Mason R, Marsden CA. 2003. Differential cannabinoid-induced electrophysiological effects in rat ventral tegmentum. Neuropharmacology 44: 633-641.

Cheer JF, Aragona BJ, Heien ML, Seipel AT, Carelli RM, Wightman RM. 2007. Coordinated accumbal dopamine release and neural activity drive goal-directed behavior. Neuron 54: 237-244.

Chevaleyre V, Piskorowski R. 2014. Modulating excitation through plasticity at inhibitory synapses. Front Cell Neurosci 8: 93.

Cobb SR, Buhl EH, Halasy K, Paulsen O, Somogyi P. 1995. Synchronization of neuronal activity in hippocampus by individual GABAergic interneurons. Nature 378: 75-78.

Colgin LL. 2016. Rhythms of the hippocampal network. Nat Rev Neurosci 17: 239-249.

Crean RD, Crane NA, Mason BJ. 2011. An evidence based review of acute and long-term effects of cannabis use on executive cognitive functions. J Addict Med 5: 1-8.

Deadwyler SA, Hampson RE. 2008. Endocannabinoids modulate encoding of sequential memory in the rat hippocampus. Psychopharmacology (Berl) 198: $577-586$.

de Lavilléon G, Lacroix MM, Rondi-Reig L, Benchenane K. 2015. Explicit memory creation during sleep demonstrates a causal role of place cells in navigation. Nat Neurosci 18: 493-495.

Del Pino I, Brotons-Mas JR, Marques-Smith A, Marighetto A, Frick A, Marin O, Rico B. 2017. Abnormal wiring of $\mathrm{CCK}^{+}$basket cells disrupts spatial information coding. Nat Neurosci 20: 784-792.

de Oliveira Alvares L, de Oliveira LF, Camboim C, Diehl F, Genro BP, Lanziotti VB, Quillfeldt JA. 2005. Amnestic effect of intrahippocampal AM251, a CB1-selective blocker, in the inhibitory avoidance, but not in the open field habituation task, in rats. Neurobiol Learn Mem 83: 119-124.

Devane WA, Dysarz FA III, Johnson MR, Melvin LS, Howlett AC. 1988. Determination and characterization of a cannabinoid receptor in rat brain. Mol Pharmacol 34: 605-613.

Devane WA, Hanus L, Breuer A, Pertwee RG, Stevenson LA, Griffin G, Gibson D, Mandelbaum A, Etinger A, Mechoulam R. 1992. Isolation and structure of a brain constituent that binds to the cannabinoid receptor. Science 258: 1946-1949.

Diba K, Buzsaki G. 2007. Forward and reverse hippocampal place-cell sequences during ripples. Nat Neurosci 10: 1241-1242.

Drew WG, Miller LL. 1974. Cannabis: neural mechanisms and behaviora theoretical review. Pharmacology 11: 12-32.

Essman EJ. 1984. Marijuana intoxication in rats: interruption of recent memory and effect on brain concentration of $\Delta^{9}$-tetrahydrocannabinol. Psychol Rep 55: 563-567.

Flagel SB, Clark JJ, Robinson TE, Mayo L, Czuj A, Willuhn I, Akers CA, Clinton SM, Phillips PE, Akil H. 2011. A selective role for dopamine in stimulus-reward learning. Nature 469: 53-57.

Foldy C, Lee SY, Szabadics J, Neu A, Soltesz I. 2007. Cell type-specific gating of perisomatic inhibition by cholecystokinin. Nat Neurosci 10: 1128-1130.

Foster DJ. 2017. Replay comes of age. Annu Rev Neurosci 40: 581-602.

Foster DJ, Wilson MA. 2006. Reverse replay of behavioural sequences in hippocampal place cells during the awake state. Nature 440: 680-683.

Foster TC, Castro CA, McNaughton BL. 1989. Spatial selectivity of rat hippocampal neurons: dependence on preparedness for movement. Science 244: 1580-1582.

French ED. 1997. $\Delta^{9}$-Tetrahydrocannabinol excites rat VTA dopamine neurons through activation of cannabinoid CB1 but not opioid receptors. Neurosci Lett 226: 159-162.

French SJ, Totterdell S. 2002. Hippocampal and prefrontal cortical inputs monosynaptically converge with individual projection neurons of the nucleus accumbens. J Comp Neurol 446: 151-165.

French ED, Dillon K, Wu X. 1997. Cannabinoids excite dopamine neurons in the ventral tegmentum and substantia nigra. Neuroreport 8: 649-652.

Freund TF, Buzsaki G. 1996. Interneurons of the hippocampus. Hippocampus 6: $347-470$.

Friend L, Weed J, Sandoval P, Nufer T, Ostlund I, Edwards JG. 2017. CB1-dependent long-term depression in ventral tegmental area GABA neurons: a novel target for marijuana. J Neurosci 37: 10943-10954.

Fuchs RA, Evans KA, Ledford CC, Parker MP, Case JM, Mehta RH, See RE. 2005. The role of the dorsomedial prefrontal cortex, basolateral amygdala, and dorsal hippocampus in contextual reinstatement of cocaine seeking in rats. Neuropsychopharmacology 30: 296-309.

Fujisawa S, Buzsaki G. 2011. A $4 \mathrm{~Hz}$ oscillation adaptively synchronizes prefrontal, VTA, and hippocampal activities. Neuron 72: 153-165.

Gan J, Weng SM, Pernia-Andrade AJ, Csicsvari J, Jonas P. 2017. Phase-locked inhibition, but not excitation, underlies hippocampal ripple oscillations in awake mice in vivo. Neuron 93: 308-314.

Gantz SC, Bean BP. 2017. Cell-autonomous excitation of midbrain dopamine neurons by endocannabinoid-dependent lipid signaling. Neuron 93: 1375-1387.e2. 
Gauthier JL, Tank DW. 2018. A dedicated population for reward coding in the hippocampus. Neuron 99: 179-193.

Ghazzaoui R, Abi-Dargham A. 2014. Imaging dopamine transmission parameters in cannabis dependence. Prog Neuropsychopharmacol Biol Psychiatry 52: 28-32.

Ginovart N, Tournier BB, Moulin-Sallanon M, Steimer T, Ibanez V, Millet P. 2012. Chronic $\Delta^{9}$-tetrahydrocannabinol exposure induces a sensitization of dopamine $\mathrm{D}(2) /(3)$ receptors in the mesoaccumbens and nigrostriatal systems. Neuropsychopharmacology 37: 2355-2367.

Gomperts SN, Kloosterman F, Wilson MA. 2015. VTA neurons coordinate with the hippocampal reactivation of spatial experience. Elife 4: e05360.

Groenewegen HJ, Vermeulen-Van der Zee E, te Kortschot A, Witter MP. 1987. Organization of the projections from the subiculum to the ventral striatum in the rat. A study using anterograde transport of Phaseolus vulgaris leucoagglutinin. Neuroscience 23: 103-120.

Gruber AJ, Hussain RJ, O'Donnell P. 2009. The nucleus accumbens: a switchboard for goal-directed behaviors. PLoS One 4: e5062.

Gruber MJ, Ritchey M, Wang SF, Doss MK, Ranganath C. 2016. Post-learning hippocampal dynamics promote preferential retention of rewarding events. Neuron 89: 1110-1120.

Gunduz-Cinar O, Hill MN, McEwen BS, Holmes A. 2013. Amygdala FAAH and anandamide: mediating protection and recovery from stress. Trends Pharmacol Sci 34: 637-644.

Hajos N, Katona I, Naiem SS, MacKie K, Ledent C, Mody I, Freund TF. 2000. Cannabinoids inhibit hippocampal GABAergic transmission and network oscillations. Eur J Neurosci 12: 3239-3249.

Hajos M, Hoffmann WE, Kocsis B. 2008. Activation of cannabinoid-1 receptors disrupts sensory gating and neuronal oscillation: relevance to schizophrenia. Biol Psychiatry 63: 1075-1083.

Hampson RE, Mu J, Deadwyler SA. 2000. Cannabinoid and kappa opioid receptors reduce potassium $\mathrm{K}$ current via activation of $\mathrm{G}(\mathrm{s})$ proteins in cultured hippocampal neurons. J Neurophysiol 84: 2356-2364.

Hampson RE, Sweatt AJ, Goonawardena AV, Song D, Chan RH, Marmarelis VZ, Berger TW, Deadwyler SA. 2011. Memory encoding in hippocampal ensembles is negatively influenced by cannabinoid CB1 receptors. Behav Pharmacol 22: 335-346.

Hansen N, Manahan-Vaughan D. 2014. Dopamine D1/D5 receptors mediate informational saliency that promotes persistent hippocampal long-term plasticity. Cereb Cortex 24: 845-858

Herkenham M, Lynn AB, Little MD, Johnson MR, Melvin LS, de Costa BR, Rice KC. 1990. Cannabinoid receptor localization in brain. Proc Natl Acad Sci 87: 1932-1936.

Herkenham M, Lynn AB, de Costa BR, Richfield EK. 1991a. Neuronal localization of cannabinoid receptors in the basal ganglia of the rat. Brain Res 547: 267-274.

Herkenham M, Lynn AB, Johnson MR, Melvin LS, de Costa BR, Rice KC. 1991b. Characterization and localization of cannabinoid receptors in rat brain: a quantitative in vitro autoradiographic study. J Neurosci 11: 563-583.

Heyser CJ, Hampson RE, Deadwyler SA. 1993. Effects of $\Delta^{9}$-tetrahydrocannabinol on delayed match to sample performance in rats: alterations in short-term memory associated with changes in task specific firing of hippocampal cells. J Pharmacol Exp Ther 264: 294-307.

Hill KP. 2015. Medical marijuana for treatment of chronic pain and other medical and psychiatric problems: a clinical review. JAMA 313: 2474-2483.

Hoffman A, Lupica C. 2000. Mechanisms of cannabinoid inhibition of GABA(A) synaptic transmission in the hippocampus. J Neurosci 20: 2470-2479.

Howlett AC, Bidaut-Russell M, Devane WA, Melvin LS, Johnson MR, Herkenham M. 1990. The cannabinoid receptor: biochemical, anatomical and behavioral characterization. Trends Neurosci 13: $420-423$.

Hyman SE, Malenka RC. 2001. Addiction and the brain: the neurobiology of compulsion and its persistence. Nat Rev Neurosci 2: 695-703.

Ito R, Robbins TW, Pennartz CM, Everitt BJ. 2008. Functional interaction between the hippocampus and nucleus accumbens shell is necessary for the acquisition of appetitive spatial context conditioning. J Neurosci $\mathbf{2 8}$ : 6950-6959.

Izumi Y, Zorumski CF. 2017. Neuregulin and dopamine D4 receptors contribute independently to depotentiation of schaffer collateral LTP by temperoammonic path stimulation. eNeuro 4 doi:10.1523/ENEURO.0176-17.2017

Jentsch JD, Verrico CD, Le D, Roth RH. 1998. Repeated exposure to $\Delta^{9}$-tetrahydrocannabinol reduces prefrontal cortical dopamine metabolism in the rat. Neurosci Lett 246: $169-172$.

John WS, Martin TJ, Solingapuram Sai KK, Nader SH, Gage HD, Mintz A, Nader MA. 2017. Chronic $\Delta^{9}$-THC in rhesus monkeys: effects on cognitive performance and dopamine D2/D3 receptor availability. J Pharmacol Exp Ther 364: 300-310.

Julian MD, Martin AB, Cuellar B, Rodriguez De Fonseca F, Navarro M, Moratalla R, Garcia-Segura LM. 2003. Neuroanatomical relationship between type 1 cannabinoid receptors and dopaminergic systems in the rat basal ganglia. Neuroscience 119: 309-318.

Jurado-Parras MT, Sánchez-Campusano R, Castellanos NP, del-Pozo F, Gruart A, Delgado-García JM. 2013. Differential contribution of hippocampal circuits to appetitive and consummatory behaviors during operant conditioning of behaving mice. J Neurosci 33: 2293-2304.

Justinova Z, Tanda G, Redhi GH, Goldberg SR. 2003. Self-administration of $\Delta^{9}$-tetrahydrocannabinol (THC) by drug naive squirrel monkeys. Psychopharmacology (Berl) 169: 135-140.

Justinova Z, Goldberg SR, Heishman SJ, Tanda G. 2005. Self-administration of cannabinoids by experimental animals and human marijuana smokers. Pharmacol Biochem Behav 81: 285-299.

Kano M, Ohno-Shosaku T, Hashimotodani Y, Uchigashima M, Watanabe M. 2009. Endocannabinoid-mediated control of synaptic transmission. Physiol Rev 89: 309-380.

Karlsson MP, Frank LM. 2009. Awake replay of remote experiences in the hippocampus. Nat Neurosci 12: 913-918.

Karson MA, Whittington KC, Alger BE. 2008. Cholecystokinin inhibits endocannabinoid-sensitive hippocampal IPSPs and stimulates others. Neuropharmacology 54: 117-128.

Karunakaran S, Chowdhury A, Donato F, Quairiaux C, Michel CM, Caroni P. 2016. PV plasticity sustained through $\mathrm{D} 1 / 5$ dopamine signaling required for long-term memory consolidation. Nat Neurosci 19: 454-464.

Katona I, Sperlagh B, Sik A, Kafalvi A, Vizi ES, Mackie K, Freund TF. 1999. Presynaptically located CB1 cannabinoid receptors regulate GABA release from axon terminals of specific hippocampal interneurons. J Neurosci 19: 4544-4558.

Katona I, Urban GM, Wallace M, Ledent C, Jung KM, Piomelli D, Mackie K, Freund TF. 2006. Molecular composition of the endocannabinoid system at glutamatergic synapses. J Neurosci 26: 5628-5637.

Katz G, Lobel T, Tetelbaum A, Raskin S. 2014. Cannabis withdrawal-a new diagnostic category in DSM-5. Isr I Psychiatry Relat Sci 51: 270-275.

Kawamura Y, Fukaya M, Maejima T, Yoshida T, Miura E, Watanabe M, Ohno-Shosaku T, Kano M. 2006. The CB1 cannabinoid receptor is the major cannabinoid receptor at excitatory presynaptic sites in the hippocampus and cerebellum. J Neurosci 26: 2991-3001.

Kempadoo KA, Mosharov EV, Choi SJ, Sulzer D, Kandel ER. 2016. Dopamine release from the locus coeruleus to the dorsal hippocampus promotes spatial learning and memory. Proc Natl Acad Sci 113: 14835-14840.

Khurana L, Mackie K, Piomelli D, Kendall DA. 2017. Modulation of CB1 cannabinoid receptor by allosteric ligands: pharmacology and therapeutic opportunities. Neuropharmacology 124: 3-12.

Kim H, Ahrlund-Richter S, Wang X, Deisseroth K, Carlen M. 2016. Prefrontal parvalbumin neurons in control of attention. Cell 164: 208-218.

Klausberger T, Marton LF, O'Neill J, Huck JH, Dalezios Y, Fuentealba P, Suen WY, Papp E, Kaneko T, Watanabe M, et al. 2005. Complementary roles of cholecystokinin- and parvalbumin-expressing GABAergic neurons in hippocampal network oscillations. J Neurosci 25: 9782-9793.

Kolb B, Li Y, Robinson T, Parker LA. 2018. THC alters alters morphology of neurons in medial prefrontal cortex, orbital prefrontal cortex, and nucleus accumbens and alters the ability of later experience to promote structural plasticity. Synapse $\mathbf{7 2}$ doi:10.1002/syn.22020

Koob GF. 1992. Drugs of abuse: anatomy, pharmacology and function of reward pathways. Trends Pharmacol Sci 13: 177-184.

Koob GF, Volkow ND. 2016. Neurobiology of addiction: a neurocircuitry analysis. Lancet Psychiatry 3: 760-773.

Kortleven C, Fasano C, Thibault D, Lacaille JC, Trudeau LE. 2011. The endocannabinoid 2-arachidonoylglycerol inhibits long-term potentiation of glutamatergic synapses onto ventral tegmental area dopamine neurons in mice. Eur J Neurosci 33: 1751-1760.

Kreitzer AC, Regehr WG. 2001. Cerebellar depolarization-induced suppression of inhibition is mediated by endogenous cannabinoids. J Neurosci 21: RC174.

Kucewicz MT, Tricklebank MD, Bogacz R, Jones MW. 2011. Dysfunctional prefrontal cortical network activity and interactions following cannabinoid receptor activation. J Neurosci 31: 15560-15568.

Laaris N, Good CH, Lupica CR. 2010. $\Delta^{9}$-Tetrahydrocannabinol is a full agonist at CB1 receptors on GABA neuron axon terminals in the hippocampus. Neuropharmacology 59: 121-127.

Lansink CS, Goltstein PM, Lankelma JV, McNaughton BL, Pennartz CM. 2009. Hippocampus leads ventral striatum in replay of place-reward information. PLoS Biol 7: e1000173.

Lansink CS, Meijer GT, Lankelma JV, Vinck MA, Jackson JC, Pennartz CM. 2016. Reward expectancy strengthens CA1 $\theta$ and $\beta$ band synchronization and hippocampal-ventral striatal coupling. J Neurosci 36: $10598-10610$

Lauckner JE, Jensen JB, Chen HY, Lu HC, Hille B, Mackie K. 2008. GPR55 is a cannabinoid receptor that increases intracellular calcium and inhibits $\mathrm{M}$ current. Proc Natl Acad Sci 105: 2699-2704.

Lepore M, Vorel SR, Lowinson J, Gardner EL. 1995. Conditioned place preference induced by $\Delta^{9}$-tetrahydrocannabinol: comparison with cocaine, morphine, and food reward. Life Sci 56: 2073-2080. 
Lichtman AH. 2000. SR 141716A enhances spatial memory as assessed in a radial-arm maze task in rats. Eur J Pharmacol 404: 175-179.

Lichtman AH, Dimen KR, Martin BR. 1995. Systemic or intrahippocampal cannabinoid administration impairs spatial memory in rats. Psychopharmacology (Berl) 119: 282-290.

Lisman JE, Grace AA. 2005. The hippocampal-VTA loop: controlling the entry of information into long-term memory. Neuron 46: 703-713.

Lisman J, Grace AA, Duzel E. 2011. A neoHebbian framework for episodic memory; role of dopamine-dependent late LTP. Trends Neurosci 34: 536-547.

Lopez-Quintero C, Perez de los Cobos J, Hasin DS, Okuda M, Wang S, Grant BF, Blanco C. 2011. Probability and predictors of transition from first use to dependence on nicotine, alcohol, cannabis, and cocaine: results of the National Epidemiologic Survey on Alcohol and Related Conditions (NESARC). Drug Alcohol Depend 115: 120-130.

Losonczy A, Zemelman BV, Vaziri A, Magee JC. 2010. Network mechanisms of $\theta$ related neuronal activity in hippocampal CA1 pyramidal neurons. Nat Neurosci 13: 967-972.

Loureiro M, Renard J, Zunder J, Laviolette SR. 2015. Hippocampal cannabinoid transmission modulates dopamine neuron activity: impact on rewarding memory formation and social interaction. Neuropsychopharmacology 40: 1436-1447.

Lu HC, Mackie K. 2016. An introduction to the endogenous cannabinoid system. Biol Psychiatry 79: 516-525.

Ludvig N, Tang HM, Gohil BC, Botero JM. 2004. Detecting location-specific neuronal firing rate increases in the hippocampus of freely-moving monkeys. Brain Res 1014: 97-109.

Lundqvist T. 2005. Cognitive consequences of cannabis use: comparison with abuse of stimulants and heroin with regard to attention, memory and executive functions. Pharmacol Biochem Behav 81: 319-330.

Luo AH, Tahsili-Fahadan P, Wise RA, Lupica CR, Aston-Jones G. 2011. Linking context with reward: a functional circuit from hippocampal CA3 to ventral tegmental area. Science 333: 353-357.

Lupica CR, Riegel AC, Hoffman AF. 2004. Marijuana and cannabinoid regulation of brain reward circuits. Br I Pharmacol 143: 227-234.

Lupica CR, Hu Y, Devinsky O, Hoffman AF. 2017. Cannabinoids as hippocampal network administrators. Neuropharmacology 124: 25-37.

Maier N, Morris G, Schuchmann S, Korotkova T, Ponomarenko A, Bohm C, Wozny C, Schmitz D. 2012. Cannabinoids disrupt hippocampal sharp wave-ripples via inhibition of glutamate release. Hippocampus 22: 1350-1362.

Mann EO, Paulsen O. 2007. Role of GABAergic inhibition in hippocampal network oscillations. Trends Neurosci 30: $343-349$.

Marchant NJ, Campbell EJ, Whitaker LR, Harvey BK, Kaganovsky K, Adhikary S, Hope BT, Heins RC, Prisinzano TE, Vardy E, et al. 2016. Role of ventral subiculum in context-induced relapse to alcohol seeking after punishment-imposed abstinence. J Neurosci 36: 3281-3294.

Marsicano G, Lutz B. 1999. Expression of the cannabinoid receptor CB1 in distinct neuronal subpopulations in the adult mouse forebrain. Eur J Neurosci 11: 4213-4225.

Martin-Fardon R, Ciccocioppo R, Aujla H, Weiss F. 2008. The dorsal subiculum mediates the acquisition of conditioned reinstatement of cocaine-seeking. Neuropsychopharmacology 33: 1827-1834.

Mátyás F, Urbán GM, Watanabe M, Mackie K, Zimmer A, Freund TF, Katona I. 2008. Identification of the sites of 2-arachidonoylglycerol synthesis and action imply retrograde endocannabinoid signaling at both GABAergic and glutamatergic synapses in the ventral tegmental area. Neuropharmacology 54: 95-107.

McGlinchey EM, Aston-Jones G. 2018. Dorsal hippocampus drives context-induced cocaine seeking via inputs to lateral septum. Neuropsychopharmacology 43: 987-1000.

McLaughlin RJ, Hill MN, Bambico FR, Stuhr KL, Gobbi G, Hillard CJ, Gorzalka BB. 2012. Prefrontal cortical anandamide signaling coordinates coping responses to stress through a serotonergic pathway. Eur Neuropsychopharmacol 22: 664-671.

McNamara CG, Tejero-Cantero A, Trouche S, Campo-Urriza N, Dupret D. 2014. Dopaminergic neurons promote hippocampal reactivation and spatial memory persistence. Nat Neurosci 17: 1658-1660.

Mechoulam R, Gaoni Y. 1965. A total synthesis of

$\mathrm{Dl}-\Delta^{1}$-tetrahydrocannabinol, the active constituent of hashish. J Am Chem Soc 87: 3273-3275.

Meier MH, Caspi A, Ambler A, Harrington H, Houts R, Keefe RS, McDonald K, Ward A, Poulton R, Moffitt TE. 2012. Persistent cannabis users show neuropsychological decline from childhood to midlife. Proc Natl Acad Sci 109: E2657-E2664.

Melis M, Frau R, Kalivas PW, Spencer S, Chioma V, Zamberletti E, Rubino T, Parolaro D. 2017. New vistas on cannabis use disorder. Neuropharmacology 124: 62-72.

Melis M, Perra S, Muntoni AL, Pillolla G, Lutz B, Marsicano G, Di Marzo V, Gessa GL, Pistis M. 2004a. Prefrontal cortex stimulation induces 2-arachidonoyl-glycerol-mediated suppression of excitation in dopamine neurons. J Neurosci 24: 10707-10715.
Melis M, Pistis M, Perra S, Muntoni AL, Pillolla G, Gessa GL, 2004b. Endocannabinoids mediate presynaptic inhibition of glutamatergic transmission in rat ventral tegmental area dopamine neurons through activation of CB1 receptors. J Neurosci 24: 53-62.

Miller KK, Hoffer A, Svoboda KR, Lupica CR. 1997. Cholecystokinin increases GABA release by inhibiting a resting $\mathrm{K}+$ conductance in hippocampal interneurons. J Neurosci 17: 4994-5003.

Miller LL, Branconnier RJ. 1983. Cannabis: effects on memory and the cholinergic limbic system. Psychol Bull 93: 441-456.

Misner DL, Sullivan JM. 1999. Mechanism of cannabinoid effects on long-term potentiation and depression in hippocampal CA1 neurons. J Neurosci 19: 6795-6805.

Miyawaki T, Norimoto H, Ishikawa T, Watanabe Y, Matsuki N, Ikegaya Y. 2014. Dopamine receptor activation reorganizes neuronal ensembles during hippocampal sharp waves in vitro. PLoS One 9: e104438.

Monory K, Polack M, Remus A, Lutz B, Korte M. 2015. Cannabinoid CB1 receptor calibrates excitatory synaptic balance in the mouse hippocampus. J Neurosci 35: 3842-3850.

Morena M, Campolongo P. 2014. The endocannabinoid system: an emotional buffer in the modulation of memory function. Neurobiol Learn Mem 112: $30-43$.

Munro S, Thomas KL, Abu-Shaar M. 1993. Molecular characterization of a peripheral receptor for cannabinoids. Nature 365: 61-65.

Murray JE, Bevins RA. 2010. Cannabinoid conditioned reward and aversion: behavioral and neural processes. ACS Chem Neurosci 1: 265-278.

Nagode DA, Tang AH, Yang K, Alger BE. 2014. Optogenetic identification of an intrinsic cholinergically driven inhibitory oscillator sensitive to cannabinoids and opioids in hippocampal CA1. J Physiol 592: 103-123.

Nasser HM, Calu DJ, Schoenbaum G, Sharpe MJ. 2017. The dopamine prediction error: contributions to associative models of reward learning. Front Psychol 8: 244 .

$\mathrm{Ng}$ Cheong Ton JM, Gerhardt GA, Friedemann M, Etgen AM, Rose GM, Sharpless NS, Gardner EL. 1988. The effects of $\Delta^{9}$-tetrahydrocannabinol on potassium-evoked release of dopamine in the rat caudate nucleus: an in vivo electrochemical and in vivo microdialysis study. Brain Res 451: $59-68$.

Ohno-Shosaku T, Shosaku J, Tsubokawa H, Kano M. 2002. Cooperative endocannabinoid production by neuronal depolarization and group I metabotropic glutamate receptor activation. Eur J Neurosci 15: 953-961.

Ólafsdóttir HF, Bush D, Barry C. 2018. The role of hippocampal replay in memory and planning. Curr Biol 28: R37-R50.

Oleson EB, Cheer JF. 2012. A brain on cannabinoids: the role of dopamine release in reward seeking. Cold Spring Harb Perspect Med 2: a012229.

Oleson EB, Beckert MV, Morra JT, Lansink CS, Cachope R, Abdullah RA, Loriaux AL, Schetters D, Pattij T, Roitman MF, et al. 2012 Endocannabinoids shape accumbal encoding of cue-motivated behavior via CB1 receptor activation in the ventral tegmentum. Neuron 73: $360-373$.

O'Mara SM. 1995. Spatially selective firing properties of hippocampal formation neurons in rodents and primates. Prog Neurobiol 45: 253-274.

Otmakhova NA, Lisman JE. 1996. D1/D5 dopamine receptor activation increases the magnitude of early long-term potentiation at CA1 hippocampal synapses. J Neurosci 16: 7478-7486.

Panlilio LV, Justinova Z. 2018. Preclinical studies of cannabinoid reward, treatments for cannabis use disorder, and addiction-related effects of cannabinoid exposure. Neuropsychopharmacology 43: 116-141.

Panlilio LV, Justinova Z, Goldberg SR. 2010. Animal models of cannabinoid reward. Br J Pharmacol 160: 499-510.

Parsons LH, Hurd YL. 2015. Endocannabinoid signalling in reward and addiction. Nat Rev Neurosci 16: 579-594.

Pelkey KA, Chittajallu R, Craig MT, Tricoire L, Wester JC, McBain CJ. 2017. Hippocampal GABAergic inhibitory interneurons. Physiol Rev 97: 1619-1747.

Pennartz CM, Ito R, Verschure PF, Battaglia FP, Robbins TW. 2011. The hippocampal-striatal axis in learning, prediction and goal-directed behavior. Trends Neurosci 34: 548-559.

Peterfi Z, Urban GM, Papp OI, Nemeth B, Monyer H, Szabo G, Erdelyi F, Mackie K, Freund TF, Hajos N, et al. 2012. Endocannabinoid-mediated long-term depression of afferent excitatory synapses in hippocampal pyramidal cells and GABAergic interneurons. J Neurosci 32: $14448-14463$.

Piomelli D. 2003. The molecular logic of endocannabinoid signalling. Nat Rev Neurosci 4: 873-884.

Pistis M, Perra S, Pillolla G, Melis M, Muntoni AL, Gessa GL. 2004. Adolescent exposure to cannabinoids induces long-lasting changes in the response to drugs of abuse of rat midbrain dopamine neurons. Biol Psychiatry 56: 86-94.

Pope HG Jr, Gruber AJ, Yurgelun-Todd D. 1995. The residual neuropsychological effects of cannabis: the current status of research. Drug Alcohol Depend 38: 25-34. 
Puighermanal E, Marsicano G, Busquets-Garcia A, Lutz B, Maldonado R, Ozaita A. 2009. Cannabinoid modulation of hippocampal long-term memory is mediated by mTOR signaling. Nat Neurosci 12: 1152-1158.

Raver SM, Keller A. 2014. Permanent suppression of cortical oscillations in mice after adolescent exposure to cannabinoids: receptor mechanisms. Neuropharmacology 86: 161-173.

Raver SM, Haughwout SP, Keller A. 2013. Adolescent cannabinoid exposure permanently suppresses cortical oscillations in adult mice. Neuropsychopharmacology 38: 2338-2347.

Retailleau A, Morris G. 2018. Spatial rule learning and corresponding CA1 place cell reorientation depend on local dopamine release. Curr Biol 28: 836-846 e834.

Richter A, Gruber O. 2018. Influence of ventral tegmental area input on cortico-subcortical networks underlying action control and decision making. Hum Brain Mapp 39: 1004-1014.

Riegel AC, Lupica CR. 2004. Independent presynaptic and postsynaptic mechanisms regulate endocannabinoid signaling at multiple synapses in the ventral tegmental area. I Neurosci 24: 11070-11078.

Robbe D, Buzsaki G. 2009. Alteration of $\theta$ timescale dynamics of hippocampal place cells by a cannabinoid is associated with memory impairment. J Neurosci 29: 12597-12605.

Robbe D, Alonso G, Duchamp F, Bockaert J, Manzoni OJ. 2001. Localization and mechanisms of action of cannabinoid receptors at the glutamatergic synapses of the mouse nucleus accumbens. J Neurosci 21: 109-116.

Robbe D, Montgomery SM, Thome A, Rueda-Orozco PE, McNaughton BL, Buzsaki G. 2006. Cannabinoids reveal importance of spike timing coordination in hippocampal function. Nat Neurosci 9: 1526-1533.

Robinson L, McKillop-Smith S, Ross NL, Pertwee RG, Hampson RE, Platt B, Riedel G. 2008. Hippocampal endocannabinoids inhibit spatial learning and limit spatial memory in rats. Psychopharmacology (Berl) 198: 551-563.

Ross RA. 2003. Anandamide and vanilloid TRPV1 receptors. Br J Pharmacol 140: $790-801$.

Rossato JI, Bevilaqua LR, Izquierdo I, Medina JH, Cammarota M. 2009. Dopamine controls persistence of long-term memory storage. Science 325: $1017-1020$

Santos LM, Dzirasa K, Kubo R, Silva MT, Ribeiro S, Sameshima K, Valle AC, Timo-Iaria C. 2008. Baseline hippocampal $\theta$ oscillation speeds correlate with rate of operant task acquisition. Behav Brain Res 190: 152-155.

Schlingloff D, Kali S, Freund TF, Hajos N, Gulyas AI. 2014. Mechanisms of sharp wave initiation and ripple generation. J Neurosci 34: 11385-11398.

Scoville WB, Milner B. 1957. Loss of recent memory after bilateral hippocampal lesions. J Neurol Neurosurg Psychiatry 20: 11-21.

Shen M, Piser TM, Seybold VS, Thayer SA. 1996. Cannabinoid receptor agonists inhibit glutamatergic synaptic transmission in rat hippocampal cultures. J Neurosci 16: 4322-4334.

Singer W. 1999. Neuronal synchrony: a versatile code for the definition of relations? Neuron 24: 49-65, 111-125.

Singer AC, Frank LM. 2009. Rewarded outcomes enhance reactivation of experience in the hippocampus. Neuron 64: 910-921.

Sjulson L, Peyrache A, Cumpelik A, Cassataro D, Buzsáki G. 2018. Cocaine place conditioning strengthens location-specific hippocampal coupling to the nucleus accumbens. Neuron 98: 926-934.e5.

Skosnik PD, Krishnan GP, D'Souza DC, Hetrick WP, O'Donnell BF. 2014. Disrupted $\gamma$-band neural oscillations during coherent motion perception in heavy cannabis users. Neuropsychopharmacology 39: 3087-3099.

Skosnik PD, Cortes-Briones JA, Hajos M. 2016. It's all in the rhythm: the role of cannabinoids in neural oscillations and psychosis. Biol Psychiatry 79: 568-577.

Solomon EA, Kragel JE, Sperling MR, Sharan A, Worrell G, Kucewicz M, Inman CS, Lega B, Davis KA, Stein JM, et al. 2017. Widespread $\theta$ synchrony and high-frequency desynchronization underlies enhanced cognition. Nat Commun 8: 1704.

Spencer S, Neuhofer D, Chioma VC, Garcia-Keller C, Schwartz DJ, Allen N, Scofield MD, Ortiz-Ithier T, Kalivas PW. 2018. A model of $\Delta^{9}$-tetrahydrocannabinol self-administration and reinstatement that alters synaptic plasticity in nucleus accumbens. Biol Psychiatry pii: S0006-3223(18)31471-9. doi:10.1016/j.biopsych.2018.04.016.

Stella N, Schweitzer P, Piomelli D. 1997. A second endogenous cannabinoid that modulates long-term potentiation. Nature 388: 773-778.

Stenner MP, Litvak V, Rutledge RB, Zaehle T, Schmitt FC, Voges J, Heinze HJ, Dolan RJ. 2015. Cortical drive of low-frequency oscillations in the human nucleus accumbens during action selection. J Neurophysiol 114: 29-39.

Substance Abuse and Mental Health Services Administration. 2017. Key substance use and mental health indicators in the United States: results from the 2016 National Survey on Drug Use and Health (HHS Publication No. SMA 17-5044, NSDUH Series H-52). Center for Behavioral Health Statistics and Quality, Substance Abuse and Mental Health Services Administration, Rockville, MD.
Sullivan JM. 2000. Cellular and molecular mechanisms underlying learning and memory impairments produced by cannabinoids. Learn Mem 7: 132-139.

Takahashi KA, Castillo PE. 2006. The CB1 cannabinoid receptor mediates glutamatergic synaptic suppression in the hippocampus. Neuroscience 139: 795-802.

Takeuchi T, Duszkiewicz AJ, Sonneborn A, Spooner PA, Yamasaki M, Watanabe M, Smith CC, Fernandez G, Deisseroth K, Greene RW, et al. 2016. Locus coeruleus and dopaminergic consolidation of everyday memory. Nature 537: 357-362.

Tamura M, Spellman TJ, Rosen AM, Gogos JA, Gordon JA. 2017. Hippocampal-prefrontal $\theta-\gamma$ coupling during performance of a spatial working memory task. Nat Commun 8: 2182.

Tanda G, Pontieri FE, Di Chiara G. 1997. Cannabinoid and heroin activation of mesolimbic dopamine transmission by a common mu1 opioid receptor mechanism. Science 276: 2048-2050.

Tournier BB, Tsartsalis S, Dimiziani A, Millet P, Ginovart N. 2016. Time-dependent effects of repeated THC treatment on dopamine D2/3 receptor-mediated signalling in midbrain and striatum. Behav Brain Res 311: $322-329$

Trimper JB, Galloway CR, Jones AC, Mandi K, Manns JR. 2017. $\gamma$ Oscillations in rat hippocampal subregions dentate gyrus, CA3, CA1, and subiculum underlie associative memory encoding. Cell Rep 21: 2419-2432.

Tryon VL, Penner MR, Heide SW, King HO, Larkin J, Mizumori SJY. 2017. Hippocampal neural activity reflects the economy of choices during goal-directed navigation. Hippocampus 27: 743-758.

Tsou K, Mackie K, Sanudo-Pena MC, Walker JM. 1999. Cannabinoid CB1 receptors are localized primarily on cholecystokinin-containing GABAergic interneurons in the rat hippocampal formation. Neuroscience 93: $969-975$.

Twitchell W, Brown S, Mackie K. 1997. Cannabinoids inhibit N- and P/Q-type calcium channels in cultured rat hippocampal neurons. J Neurophysiol 78: 43-50.

United Nations Office on Drugs and Crime. 2016. World Drug Report 2016.

van de Giessen E, Weinstein JJ, Cassidy CM, Haney M, Dong Z, Ghazzaoui R, Ojeil N, Kegeles LS, Xu X, Vadhan NP, et al. 2016. Deficits in striatal dopamine release in cannabis dependence. Mol Psychiatry 22: 68-75.

van der Meer MA, Redish AD. 2011. $\theta$ phase precession in rat ventral striatum links place and reward information. J Neurosci 31: 2843-2854.

Vandevoorde SV. 2008. Overview of the chemical families of fatty acid amide hydrolase and monoacylglycerol lipase inhibitors. Curr Top Med Chem 8: 247-267.

Varela F, Lachaux JP, Rodriguez E, Martinerie J. 2001. The brainweb: phase synchronization and large-scale integration. Nat Rev Neurosci 2: 229-239.

Varma N, Carlson GC, Ledent C, Alger BE. 2001. Metabotropic glutamate receptors drive the endocannabinoid system in hippocampus. J Neurosci 21: RC188.

Vemuri VK, Makriyannis A. 2015. Medicinal chemistry of cannabinoids. Clin Pharmacol Ther 97: 553-558.

Verrico CD, Jentsch JD, Roth RH. 2003. Persistent and anatomically selective reduction in prefrontal cortical dopamine metabolism after repeated, intermittent cannabinoid administration to rats. Synapse 49: 61-66.

Volkow ND, Baler RD, Compton WM, Weiss SR. 2014a. Adverse health effects of marijuana use. N Engl J Med 370: 2219-2227.

Volkow ND, Wang GJ, Telang F, Fowler JS, Alexoff D, Logan J, Jayne M, Wong C, Tomasi D. 2014b. Decreased dopamine brain reactivity in marijuana abusers is associated with negative emotionality and addiction severity. Proc Natl Acad Sci 111: E3149-E3156.

Volkow ND, Koob GF, McLellan AT. 2016a. Neurobiologic advances from the brain disease model of addiction. $N$ Engl J Med 374: 363-371.

Volkow ND, Swanson JM, Evins AE, DeLisi LE, Meier MH, Gonzalez R, Bloomfield MA, Curran HV, Baler R. 2016b. Effects of cannabis use on human behavior, including cognition, motivation, and psychosis: a review. JAMA Psychiatry 73: 292-297.

Volkow ND, Hampson AJ, Baler RD. 2017. Don't worry, be happy: endocannabinoids and cannabis at the intersection of stress and reward. Annu Rev Pharmacol Toxicol 57: 285-308.

Vorel SR, Liu X, Hayes RJ, Spector JA, Gardner EL. 2001. Relapse to cocaine-seeking after hippocampal $\theta$ burst stimulation. Science 292: $1175-1178$.

Walker JM, Huang SM, Strangman NM, Tsou K, Sanudo-Pena MC. 1999. Pain modulation by release of the endogenous cannabinoid anandamide. Proc Natl Acad Sci 96: 12198-12203.

Wang H, Lupica CR. 2014. Release of endogenous cannabinoids from ventral tegmental area dopamine neurons and the modulation of synaptic processes. Prog Neuropsychopharmacol Biol Psychiatry 52: 24-27.

Wang H, Treadway T, Covey DP, Cheer JF, Lupica CR. 2015. Cocaine-induced endocannabinoid mobilization in the ventral tegmental area. Cell Rep 12: 1997-2008. 
Wenzel JM, Rauscher NA, Cheer JF, Oleson EB. 2015. A role for phasic dopamine release within the nucleus accumbens in encoding aversion: a review of the neurochemical literature. ACS Chem Neurosci 6: 16-26.

Wenzel JM, Oleson EB, Gove WN, Cole AB, Gyawali U, Dantrassy HM, Bluett RJ, Dryanovski DI, Stuber GD, Deisseroth K, et al. 2018. Phasic dopamine signals in the nucleus accumbens that cause active avoidance require endocannabinoid mobilization in the midbrain. Curr Biol 28: 1392-1404.e5.

Wiebelhaus JM, Grim TW, Owens RA, Lazenka MF, Sim-Selley LJ, Abdullah RA, Niphakis MJ, Vann RE, Cravatt BF, Wiley JL, et al. 2015. $\Delta$ 9-Tetrahydrocannabinol and endocannabinoid degradative enzyme inhibitors attenuate intracranial self-stimulation in mice. J Pharmacol Exp Ther 352: 195-207.

Wikenheiser AM, Redish AD. 2015. Hippocampal $\theta$ sequences reflect current goals. Nat Neurosci 18: 289-294.

Wilson RI, Nicoll RA. 2001. Endogenous cannabinoids mediate retrograde signalling at hippocampal synapses. Nature 410: $588-592$.

Wilson RI, Nicoll RA. 2002. Endocannabinoid signaling in the brain. Science 296: $678-682$.

Wise RA, Bozarth MA. 1987. A psychomotor stimulant theory of addiction. Psychol Rev 94: 469-492.
Wise LE, Thorpe AJ, Lichtman AH. 2009. Hippocampal CB(1) receptors mediate the memory impairing effects of $\Delta^{9}$-tetrahydrocannabinol. Neuropsychopharmacology 34: 2072-2080.

Wolff MC, Leander JD. 2003. SR141716A, a cannabinoid CB1 receptor antagonist, improves memory in a delayed radial maze task. Eur J Pharmacol 477: 213-217.

Yamamoto J, Suh J, Takeuchi D, Tonegawa S. 2014. Successful execution of working memory linked to synchronized high-frequency $\gamma$ oscillations. Cell 157: 845-857.

Zehra A, Burns J, Liu CK, Manza P, Wiers CE, Volkow ND, Wang GJ. 2018. Cannabis addiction and the brain: a review. J Neuroimmune Pharmacol doi:10.1007/s11481-018-9782-9.

Zimmerberg B, Glick SD, Jarvik ME. 1971. Impairment of recent memory by marihuana and THC in rhesus monkeys. Nature 233: 343-345.

Zlebnik NE, Cheer JF. 2016. Drug-induced alterations of endocannabinoid-mediated plasticity in brain reward regions. J Neurosci 36: $10230-10238$.

Received June 4, 2018; accepted in revised form July 6, 2018. 


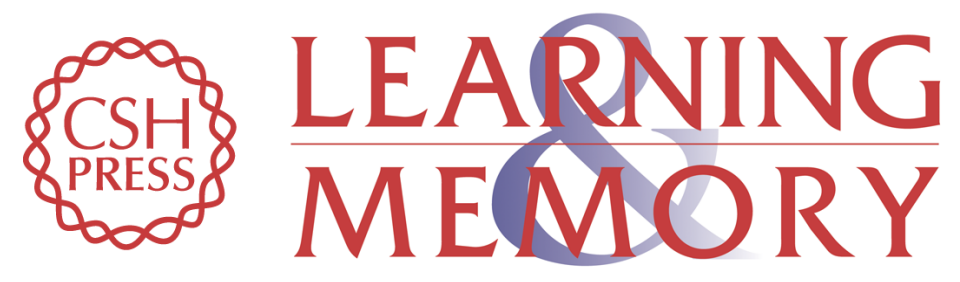

\section{Cannabinoid disruption of learning mechanisms involved in reward processing}

Carl R. Lupica and Alexander F. Hoffman

Learn. Mem. 2018, 25:

Access the most recent version at doi:10.1101/Im.046748.117

References This article cites 220 articles, 49 of which can be accessed free at: http://learnmem.cshlp.org/content/25/9/435.full.html\#ref-list-1

License This is a work of the US Government.

Email Alerting Receive free email alerts when new articles cite this article - sign up in the box at the Service top right corner of the article or click here. 